УДК 623.618 .5

Олександр Свгенович Скворчевський (кандидат технічних наук, доцент)

Національний технічний університет «Харківський політехнічний інститут», Харків, Украӥна

\title{
CALS- КОНЦЕПЦІЯ ЛОГІСТИЧНОї ПІДТРИМКИ ЖИТТЄВОГО ЦИКЛУ ОЗБРОЄННЯ ТА ВІЙСЬКОВОЇ ТЕХНІКИ: НАЦІОНАЛЬНІ АСПЕКТИ ВПРОВАДЖЕННЯ
}

В статті обтрунтована актуальність впровадження інтегрованої логістичної підтримки життєвих циклів зразків озброєння та військової техніки, щэо проектується, виробляються, експлуатуються та утилізуються в Украӥні. Показано, щуо найбільш ефективним та розповсюдженим у світі інструментом реалізації інтегрованої логістичної підтримки є CALS-концепиї (Continиои Acquisition and Life Cycle Support concept). Лідером в обраному напрямку досліджень є Сполучені штати Америки, де CALS-концепція зародилася в середині 80-х років XX cm. Сьогодні, не зважаючи на дуже високий рівень стандартизачії у сфері CALS-технологій та систем існують національні особливості імплементаиії CALS-концепиії в практику менеджменту життєвого изиклу зразків озброєння та військової техніки різних краӥн. Метою статті є виявлення викликів, які можуть виникнути на шляху впровадження CALS-конщепції в украӥнський оборонно-промисловий комплекс та силові структури. Поставлена задача вирімувалась шляхом аналізу та узагальнення досвіду впровадження інтегрованоі логістичної підтримки життєвого циклу зразків озброєння та військової техніки (на основі CALSтехнологій та систем) в краӥнах членах NATO, які за територію, військовим, промисловим, науковим потенціалом можна порівняти з Украӥною. У якості таких країн були обрані Французька Республіка, Іспанія, Італія, Німеччина. Виділені виклики та шляхи їх подолання, характерні для кожної із країн. Показано як ией досвід може бути застосований в Украӥні. Так досвід Франиузької Республіки обтрунтовує дочільність інтеграції наявних в державі інформаційних систем, наприклад різного роду реєстрів, системи Прозорро тощо, до інформаційних систем підтримки життєвого циклу озброєння та військової техніки. Досвід Іспанї важливий для прозорого иіноутворення вартості життєвого циклу. Італія впроваджує останню тенденцію в цій галузі - логістику ефективності. В Німеччині існує CALS-форум - платформа для об'єднання та обміну досвідом спеціалістів в цій галузі. Дані дослідження мають стати фундаментом для подальшого розвитку CALS-систем для озброєння та військової техніки, щчо розробляються та модернізуються в Украӥні в умовах гібридної війни.

Ключові слова: CALS-концепџія, інтегрована логістична підтримка, озброєння та військова техніка, вартість життєвого циклл, логістика ефективності, підтримка життєвого циклу продукту, ISO 10303-239, CALS-форум Німеччини

\section{Вступ}

Постановка проблеми. Поточна військовополітична ситуація в Україні вимагає швидкого та ефективного реформування та модернізації Збройних Сил України, Національної Гвардії та інших підрозділів МBC, а також Державного концерну «Укроборонпром». Одним із напрямків такої модернізації є впровадження інформаційних технологій на усіх рівнях вищеперелічених організацій. Прикладами таких напрямків, які реалізуються впродовж тривалого часу в Україні є єдина інформаційна система управління оборонними ресурсами (Defence resources management information system - DRMIS) створення якої до 30 грудня 2020 р. задекларовано дорожньою картою оборонної реформи України за 2016-2020 рр. Напрями реформування обороннопромислового комплексу України задекларовані ДК «Укроборонпром», а саме корпоратизація, кластеризація, аудит, захист технологій та запуск Головної агенції передових досліджень і розробок
(ГАРДА) також вимагають широкого застосування інформаційних технологій.

Для забезпечення ефективного розвитку інформаційних технологій логістичної підтримки життєвих циклів зразків озброєння та військової техніки доцільно звернутися до досвіду Сполучених Штатів Америки та інших країнчленів НАТО. Цьому є як мінімум дві причини. По-перше, починаючи з 2014 року Україною задекларований та реалізується чіткий напрямок євроатлантичної інтеграції. Так, наприклад створена на базі Національного технічного університету України «Київський політехнічний інститут» Головна агенція передових досліджень і розробок ДК «Укроборонпром» $\epsilon$ аналогом американської Агенції передових оборонних дослідницьких проектів (Defence По-друге, піонером впровадження інформаційних технологій у військову сферу та військово-промисловий комплекс є США, де вже з середини 1980-х почали розвиватися технології безперервної

(C) О.С. Скворчевський

Modern Information Technologies in the Sphere of Security and Defence № 1(34)/2019 ISSN2311-7249(Print)/ISSN2410-7336(Online) 
інформаційної підтримки поставок та життєвого циклу складної технічної продукції. Англійська абревіатура CALS-технологій (Continuous Acquisition and Lifecycle Support) широко увійшла до вжитку спочатку в країнах НАТО, а потім і в багатьох інших країнах світу. Причому CALSконцепція набула популярності не тільки при логістичному супроводі озброєння та військової техніки, але і цивільної високотехнологічної продукції.

Аналіз останніх досягнень та публікацій. Зацікавленість спеціалістів зі всього світу в застосуванні CALS-технологій у військовий та цивільній сферах спонукало NATO CALS Office (NCO) опублікувати проект довідника NATO 3 CALS-технологій в січні 1996. Цей продукт розповсюдився по всьому світу та був перекладений на багато світових мов. Наступний проект довідника $є$ розширенням та доповненням попередньої версії. NCO бачить цей довідник, як живий документ, який в перспективі буде знаходитися на Web-платформі та постійно оновлюватись, по мірі того, як нова інформація стане доступною [1]. Концепції, викладені в [1] знайшли подальший розвиток в доповідях та стандартах NATO, наприклад [2, 3 та ін.]. Однак, тим не менше, базовим документом на який доцільно спиратися при розгляді моделей реалізації CALS-концепції $є$ [1].

Існує ряд вітчизняних публікацій в яких розглянуті деякі практичні напрямки використання CALS-концепції [4, 5 та ін.]. Однак в них, в основному, приділяється увага використанню інтегрованої логістичної підтримки на основі CALS-концепції продукції машинобудування цивільного призначення.

Робота [6] $є$ однією із перших в якій комплексно розглядаються питання розробки вітчизняних CALS-технологій в оборонній сфері. Показана важливість побудови систем інтегрованої логістичної підтримки зразків озброєння та військової техніки із застосуванням CALS-концепції. Підкреслюється, що сучасні замовники продукції військового призначення, в рамках проведення міжнародних тендерів на закупівлю озброєння до армій держав світу, висувають до виробників вимоги щодо відповідності системі CALS-концепції. Показано, що на даний момент в країнах колишнього СРСР системи інтегрованої логістичної підтримки знаходяться на стадії розробки та закінчених рішень у цій області немає. Для ефективної організації взаємодії учасників життєвого циклу озброєння та військової техніки в режимі реального часу запропонована система інтегрованої логістичної підтримки життєвого циклу зразку озброєння. Показана важливість створення ефективної та гнучкої бази даних, яка б містила достатню кількість інформації про зразок озброєння та військової техніки. Значна частина статті [6] присвячена напрацюванням Російської Федерації в обраному напрямку досліджень, що є дуже важливим оскільки обороно-промисловий комплекс, як Російської Федерації так і України має схожі виклики, через рудименти радянської системи управління розробкою та виробництвом об’єктів озброєння та військової техніки. Також присутній аналіз досвіду країн членів НАТО в цій галузі, однак цей аналіз потребує значного розширення та розвитку.

В статті [7] розглянуто різні підходи і сучасні методи інтеграції автоматизованих систем управління 3 точки зору створення єдиної інформаційної системи управління оборонними ресурсами (Defence resources management information system - DRMIS) Збройних Сил України. Наведено основні принципи та переваги кожної з технологій. В статті загадуються CALSтехнології, як одна із складових DRMIS. Однак в [7] CALS-концепція в повній мірі не розглядається як компонент, що супроводжує зразки озброєння та військової техніки на усіх етапах їх життєвого циклу i таким чином інтегрує замовника озброєння, розробників, виробників, субпідрядників, організації що займаються утилізацією тощо.

В статті [8] вивчено основні нормативні документи та наукові публікації зарубіжних країн, в першу чергу країн-членів НАТО. Дані дослідження мають стати фундаментом для подальшого розвитку CALS-систем для озброєння та військової техніки, що розробляються та модернізуються в умовах гібридної війни. Незважаючи на те, що існує значна кількість загальних керівних документів та стандартів НАТО досвід та виклики, що виникають на етапі впровадження цих технологій в конкретних країнах $\epsilon$ індивідуальним і заслуговує окремого аналізу.

Метою даної статті $є$ аналіз та узагальнення досвіду впровадження інтегрованої логістичної підтримки життєвого циклу зразків озброєння та військової техніки (на основі CALS-технологій) в країнах членах NATO, які за територію, військовим, промисловим, науковим потенціалом можна порівняти з Україною. Виявлення викликів, що виникали у Французької Республіки, Іспанії, Італії, Німеччини на цьому шляху. Дослідження шляхів їх подолання та можливості використання цього досвіду при впровадженні CALS-концепції в Україні.

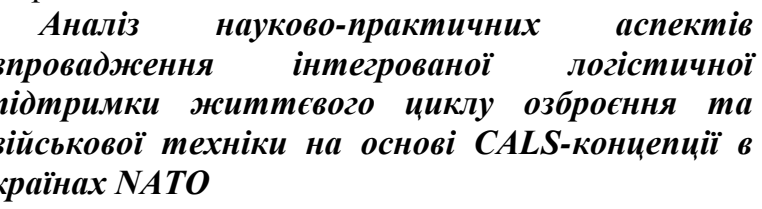

Як було сказано вище, розробником та піонером впровадження інтегрованої логістичної підтримки життєвого циклу зразків озброєння та військової техніки на основі CALS-концепції $\epsilon$ США. Впровадження інновацій в цій галузі в партнерах США по NATO має певну специфіку характерну для кожної окремої країни. У якості об'єктів аналіз та порівняння використаємо європейськім країни, які за територією, кількістю населення, військовому, військово-промисловому 
та науковому потенціалу аналогічні Україні. На початку 90-х років XX ст. Україну за вищезазначеними ознаками порівнювали iз Французькою Республікою. Тож аналіз почнемо саме із цієї країни.

В доповіді [9] представлені напрямки ратифікації, дослідження та впровадження логістичної підтримки життєвого циклу продукту (Product Life Cycle Support - PLCS) для обміну даними між Міністерством оборони Франції та промисловістю. В [9] представлено організаційну структуру Міністерства оборони Французької Республіки. У якостей основних цілей створення логістичної системи декларуються наступні:

- побудову однієї центральної логістичної інформаційної системи для кожного середовища (повітря, земля, море);

- забезпечення інтерфейсу кожної із вище перелічених логістичних систем iз CHORUS. CHORUS - міжвідомчий проект, запущений Французькою Республікою у 2007 році для заміни додатка керування державними витратами ACCORD.

Також показано, що Франція спершу ратифікувала стандарти (зокрема ISO 10303-239 (PLCS) міжнародний стандарт, котрий визначає інформаційну модель, що визначає яка інформація може бути представлена та підлягає обміну для підтримки продукту протягом його життевого циклу. Це забезпечується шляхом використання мови інформаційного моделювання EXPRESS), пов'язані із логістичною підтримкою життєвого циклу продукту без правозастосування, провела випробування на обмеженій кількості продуктів перед повною ратифікацією стандартів. Представлена архітектура мережі, яка забезпечує комунікацію учасників життєвого циклу озброєння та військової техніки, яка відзначається наступними рисами. По-перше сітка ізольована від Інтернет. По-друге, з'єднання між військовими і промисловістю здійснюється через безпечне ENX3'єднання. ENX - мережа європейської асоціації виробників, постачальників та інших організацій пов'язаних із транспортними засобами. Детально розглянуті етапи i напрямки впровадження логістичної підтримки життєвих циклів продуктів. Показано, що базисом застосування PLCS є CALSконцепція, етапи розвитку якої представлені в доповіді. CALS-концепція поділяється на CALSсистеми та CALS-технології. Базовою системою, яка $\epsilon$ апаратною частиною реалізації CALSконцепції $\epsilon$ система обміну даними. Раціональність організації схеми визначає надійність системи, ії стійкість та ефективність в плані відсутності дублювання інформації. В представлено схематичне зображення системи обміну даними між учасниками життєвого циклу озброєння та військової техніки сил наземних операцій (рис. 1) [9].

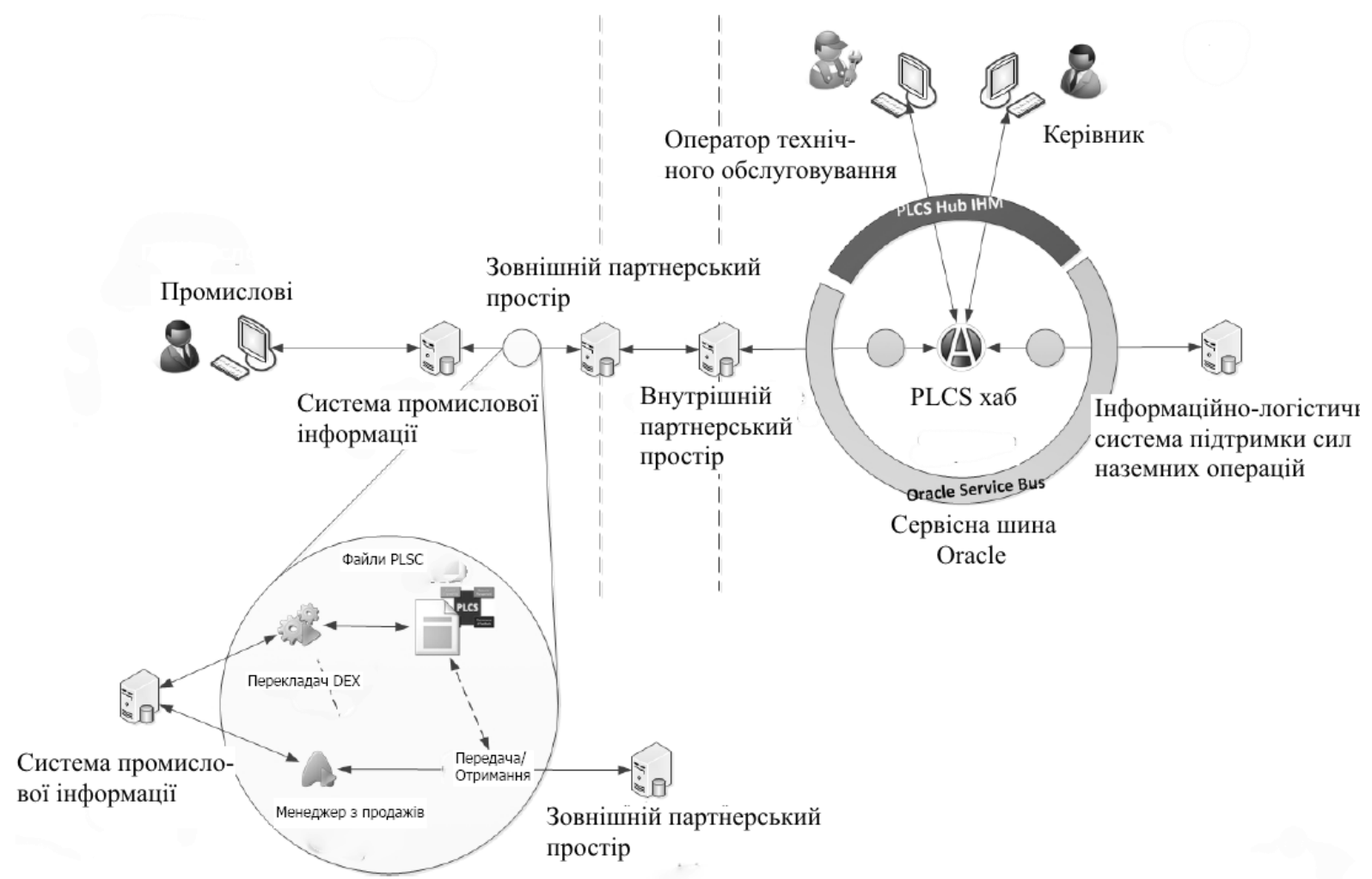

Рис. 1 - Обмін даними: інтеграція в партнерське середовище інформаційно-логістичної системи сил наземних операцій

Досвід Французької Республіки по впровадженню PLCS, що базується на стандарті ISO 10303-239 та інших нормативних документах може бути застосований в Україні при врахуванні відмінностей та військово-політичні особливості сучасного розвитку нашої держави та Французької Республіки. Актуальність вивчення та впровадження в практику PLCS також 
підтверджується нещодавнім прийняттям національного стандарту ДСТУ ISO 10303239:2018 (ISO 10303-239:2012, IDT) Системи промислової автоматизації та інтеграції. Подання даних щодо продуктів та обмін. Частина 239. Протокол додатків. Підтримування життєвого циклу продукту - На заміну ДСТУ ISO 10303 239:2007, гармонізованого із міжнародним стандартом, методом підтвердження 3 наданням чинності [10]. Метод підтвердження означає впровадження стандарту ISO англійською мовою «як є», що обгрунтовує необхідність створення вітчизняних наукових напрацювань та термінологічного забезпечення цієї галузі.

Іспанські дослідники приділяють значну увагу питанням оцінки вартості життевого циклу озброєння та військової техніки. Так у [11] вказано, що інструкція 67/2011 SEDEF/MINISDE /ESPAÑA в Іспанії регулює процес закупки матеріальних ресурсів 3 урахуванням їх життєвого циклу. Для того щоб здійснити первинну оцінку програми у відповідності із умовами затребуваного військово-технічного проекту використовується оцінка вартості життєвого циклу, як інструмент прийняття управлінського рішення. Існуюча процедура оцінки вартості життєвого циклу (Life-Cycle Cost (LCC)) оборонних програм в Іспанії представлена в [11]. B ece [11] проводиться порівняння процедури LCC в Іспанії 3 аналогічними процедурами наднаціональних організацій до яких належить країна (NATO/OCCAR). В роботі представлені загальні методи та техніки оцінки вартості життєвого циклу, оцінки можливостей, витрат та зусиль по створенню озброєння та військової техніки. Акцентується увага на особливостях процедури оцінки вартості його життєвого циклу в Іспанії. Проведено кількісний аналіз використання різних типів технік, параметрів та схем в оцінці вартості життєвого циклу озброєння та військової техніки.

Одним із основних висновків, які робить автор за результатами дослідження [11] є те, що в Іспанії не існує ефективної системи інформаційного менеджменту, яка б дозволяла отримувати дані про повні витрати або хоча б часткові витрати на життєвий цикл наявних систем озброєння. Надійність інформації, що зберігається в гетерогенних системах $є$ низькою, а ресурси необхідні на отримання та обробку цієї інформації, котра обслуговується на різних носіях та в різних форматах є значними. Крім того, інформація, отримана від компаній, $\epsilon$ однобічною та представляється в форматах, які складно обробляти [11]. Даний висновок є вкрай цінним для України через те, що показує надзвичайну важливість створення уніфікованої системи інформаційного менеджменту, яка б дозволяла покращити комунікацію між учасниками життєвого циклу озброєння та військової техніки, що в результаті дасть змогу знизити LCC.

Наступним висновком автора [11] є те, що потрібно досягти прогресу щодо симетрії інформації (рівномірного розподілу інформації) 3 промисловістю. Оскільки близько $80 \%$ рахунків в оборонній сфері в Іспанії виставлено в межах обмеженої групи з шести компаній, для того, щоб розвинути інформаційну симетрію, було б доцільно інтегрувати експертів 3 оцінки витрат в команду управління оборонною програмою. Більше того, більшість іспанських державних компаній, які $є$ постачальниками міністерства оборони, перенасичені. Заробітна плата їх співробітників є вищою, ніж в решті сектору, а умови праці є сприятливішими. Мета їх директорів полягає в тому, щоб уникнути порівняння їх вартості 3 ефективними витратами. Саме тому доцільно виділити додаткові витрати пов'язані із вищевказаними недоліками, так щоб вони покривалися Міністерством промисловості [11].

Створення інтегрованих команд проекту в числі яких були б незалежні експерти 3 оцінки витрат вцілому є дуже корисним для підвищення прозорості ціноутворення в українському військово-промисловому комплексі. Принцип незалежного нагляду уже використовується в ДК «Укроборонпром». До наглядової ради входять представники Збройних Сил, служби фінансового моніторингу України, наукової спільноти та іноземний експерт [12, 13]. Досвід вищої заробітної платні та кращих умов праці в оборонно-промисловій галузі був би позитивний для України, тому що збільшив би приплив талановитої молоді в цю сферу.

B [11] обгрунтовано взаємозв'язок між LCC та системами зберігання та обробки інформації. Показано, що кодифікація інформації із використанням декомпозиції структури, іiі зберігання та обробки в централізованих системах управління $\epsilon$ основними складовими отримання даних, які в подальшому можна буде використати для створення моделей оцінки витрат.

Вказується, що необхідно створити постійний офіс для управління програмами, який би було укомплектовано фахівцями, які спеціалізувалися на управлінні, а також який би був каналом ноухау, займався організацією, координацією між програмами, контактами із засобами масової інформації та аналізом отриманого досвіду, а також розвивав програми лідерства, розробки та управлінням політикою, процедурами, шаблонами та іншою документацією. Крім того, їй буде доручено керувати інтегрованими командами 3 управління шістьма вищезазначеними компаніями. Іспанські фахівці, які займають керівні посади в OCCAR/HATO, повинні бути зобов'язані виконувати аналогічні функції в самій Іспанії. Працівників збройних сил, які цього бажають, слід заохочувати до розвитку своєї кар'єри в рамках управління програмою. Необхідно підтримувати інституційну підготовку, а також тренування в престижних міжнародних центрах де вони повинні набувати додаткових компетенцій за межами Міністерства оборони Іспанії. В аналітичному огляді [11] обгрунтовується доцільність впровадження техніки аналізу вартості життєвого 
циклу, як частини процедури надання контрактів виконавцям. Також автори [11] на основі бази даних звітів з кошторису та досвіду, отриманого за чотири роки, робить наступні рекомендації:

- доцільність залучення технічного органу, який мав би компетенцію 3 оцінки вартості життєвого циклу для кожного етапу процесу закупівель, до моменту підписання контракту 3 придбання ресурсу та дотримання рекомендацій, викладених у його звітах;

- усім учасниками життєвого циклу сприяти формуванню факторів, коефіцієнтів, параметрів i правил канонічного кодування інформації, що характеризують життєвий цикл;

- регулювати мінімальні терміни, залежно від типу програми, доступні для експертів на кожному етапі життєвого циклу для цілей оцінки;

- обмежити терміновість обробки документів, що виникають в результаті кожної фази життєвого циклу, щоб це не призводило до того, що кошторис витрат виконується із використанням грубих оцінок, або не виконується зовсім;

- розробити проект публікації, що слугуватиме набором керівних принципів для виконання декомпозиції структур продукту, робіт вартості;

- розрахунки, формати, методи та інструменти, що використовуються в оцінках, повинні бути доступними та супроводжувати документи, розроблені на кожному етапі;

- робочі групи, створені для оцінки реалізації угоди, повинні бути небюрократичними та контролюватися постійним офісом для управління програмами або професійним фахівцем. Професійні критерії членів групи повинні переважати над рангом у цій групі, тим самим відмежовуючи експертів від будь-яких ієрархічних відносин з групою та органом, який іiі створив;

- функціональна структура організації повинна розвиватися, орієнтуючись на проекти.

Протягом останніх десятиліть міністерство оборони Італії також намагалося відкрити для себе нові методи логістичної підтримки. У зв’язку із цим у Білій Книзі 2015 року підкреслювалась необхідність перегляду моделі управління закупівлями, логістичною підтримкою, яка б включала існуючі процедури, структури і норми, на основі зразків приватних компаній та керуючись базовими принципами ефективності та результативності. В огляді [14] вказується, що матеріально-технічне забезпечення часто вважалося допоміжним питанням в стратегіях оборонних закупівель військових відомствах багатьох країн, це мало негативний вплив, як на ефективність системи, так і на результативність процесу. Останнім часом нові тенденції призвели до того, що логістична підтримка стає усе більш важливою, як у оперативному, так i в технологічно-промисловому плані, із поступовим переходом до логістичних моделей основаних на ефективності (performance-based logistics) логістика ефективності. Ці моделі здійснили революцію в логістичній підтримці, зобов'язавши постачальників забезпечити конкретні показники ефективності систем. В роботі [14] коротко розглянуто розвиток і сучасні тренди логістичної підтримки у військовій сфері, порівнюються традиційні та основані на ефективності логістичні моделі. Дається посилання на документ [15] в якому вказано, що логістикою ефективності $\epsilon$ синонімом підтримки життєвого циклу продукту, основаної на його ефективності. В даному випадку переваги досягаються за допомогою механізмів в основу яких покладено результативність, що забезпечує тактико-технічні характеристики та стимулює постачальників логістичної підтримки продукту зменшувати вартість за допомогою використання інновацій. Цими механізмами $\epsilon$ контракти з промисловістю або внутрішньоурядові угоди. Ефективність тут визначається набором спеціальних показників $[14,15]$. Різниця між традиційним підходом та логістикою ефективності показана на рис. 2 [14].

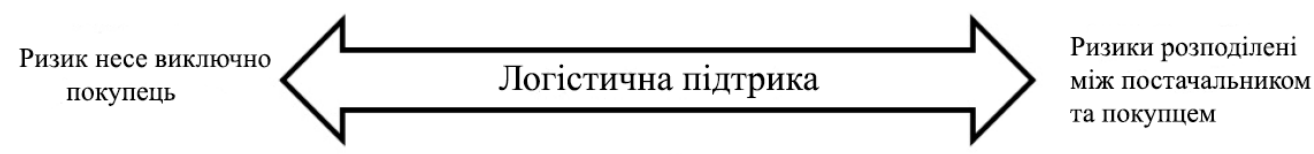

\begin{tabular}{|l|l|}
\hline Традиційний підхід & Логістика результатів \\
\hline
\end{tabular}

\begin{tabular}{|c|c|}
\hline Традиційна підтримка & Результативність \\
\hline Придбання товарів та послуг & Придбання результатів \\
\hline Рівень відповідальності постачальника Л & Рівень відповідальності постачальника个 \\
\hline $\begin{array}{l}\text { Промисловість/уряд = постачальник/клієнт } \\
\text { відношення }\end{array}$ & Партнерство промисловість/уряд \\
\hline Реактивні & Проактивні \\
\hline $\begin{array}{l}\text { Ширші вимоги } \\
\text { Більш високі витрати в довгостроковій } \\
\text { перспектив1 } \\
\text { Значні ризики клієнта }\end{array}$ & $\begin{array}{l}\text { Конкретніші вимоги } \\
\text { 3меншення.витрат в довгостроковій } \\
\text { перспективі } \\
\text { Розділяє ризики }\end{array}$ \\
\hline Модернізація вимагає значних інвестицій & $\begin{array}{l}\text { Постійна модернізація забезпечується за } \\
\text { рахунок стимулювання }\end{array}$ \\
\hline
\end{tabular}

Рис. 2 - Порівняльна схема традиційного логістичного підходу та логістики ефективності 
Також в огляді [14] обгрунтована важливість сучасної логістики взагалі та логістики ефективності зокрема для проведення реформи Збройних Сил Італії.

В презентації [16] одного з провідних фахівців у галузі досліджень Peter Janatschek, представника DATAGROUP BGS, Німеччина показано, що базисом менеджменту життєвого циклу озброєння та військової техніки є стандарти та специфікації. Окрім цього розглядається функціонування асоціації CALS Forum Deutschland (CFD), яка була заснована в 2000 році. Як незалежна та компетентна платформа CALS Forum Deutschland сприяє інтересам своїх членів у їх взаємодії із представниками уряду, суспільства, торгівлі, промисловості, науки та представляє їх в національних і міжнародних організаціях і органах влади. У CFD члени концентрують свої можливості в областях і дисциплінах, пов'язаних iз інтегрованим управлінням життєвим циклом високотехнологічної продукції. Сьогодні CFD, будучи центром мережі, представляє незалежний i компетентний логістичний форум як для державних користувачів, так і для промисловості. Починаючи з 2000 року, вона стала центром логістичної компетенції, орієнтованої на управління життєвим циклом та інтеграцію спеціалістів у цій галузі [16]. Досвід створення CALS був би дуже корисний для України, оскільки дозволив би об'єднати спеціалістів, що працюють в цьому напрямку в рамках єдиної платформи.

\section{Висновки та перспективи подалыших} досліджень

В результаті проведеного аналітичного дослідження із досвіду впровадження інтегрованої логістичної підтримки життєвого циклу зразків озброєння та військової техніки можна у кожної розглянутої країни запозичити корисний довід для впровадження CALS-концепції у вітчизняні силові структури, обороно-промисловий комплекс, наукові організації.

Досвід Французької Республіки показує нам наступне:

- стандарти ISO та внутрішні стандарти та специфікації NATO доцільно приймати в декілька етапів. Перший етап - прийняття без примусового правозастосування. На цьому етапі проводиться апробація стандартів та специфікацій на пілотних проектах. Після аналізу отриманого досвіду, практичної підготовки кваліфікованих фахівців, врахування наявних помилок та складнощів тощо стандарти та специфікації стають обов'язковими для усіх учасників життєвого циклу високотехнологічної продукції, наприклад озброєння та військової техніки;

- при побудові інформаційних CALS-систем доцільно використовувати уже наявну в державі інформаційну інфраструктуру, в Україні такими системами можуть бути різного роду реєстри, система Прозорро тощо.

Іспанські дослідники приділяють значну увагу прозорості формування вартості життєвого циклу зразків озброєння та військової техніки. Для цього рекомендується створювати незалежні наглядові ради. Для України ця рекомендація $\epsilon$ дуже актуальною оскільки ДП «Укроборонпром» декларує принципи прозорості та відкритості, має незалежну наглядову раду тощо. Інша рекомендація науковців Іспанії $\epsilon$ створення інформаційних систем які б зберігали та обробляли статистичні дані, що виникають на усіх етапах життєвого циклу високотехнологічної продукції. Наявність таких даних дозволить створювати математичні моделі вартості життєвого циклу наявних об'єктів та екстраполювати їх нові зразки озброєння та військової техніки. Такий підхід був би дуже корисний для України.

В ході реформи Збройних Сил Італії пропонується перехід від традиційної логістики до так званої performance-based logistics - логістика ефективності. В якій чітко визначається набір показників (метрики) ефективності задач, які виконує зразок озброєння або військової техніки. Таким чином замовник отримуе не зразок озброєння, а результат виконання певної задачі із певною ефективністю, набір показників для оцінки якої визначений заздалегідь.

На даному початковому етапі розвитку CALSсистем та технологій в Україні найбільш цінним виглядає досвід Німеччини де існує CALS-форум Німеччини. Для подальшого розвитку цього науково-практичного напрямку в нашій державі вкрай важлива взаємодія та інтеграція спеціалістів силових відомств, військово-промислового комплексу, науковців зайнятих розробкою, виробництвом, експлуатацією та утилізацією різних видів озброєння та військової техніки.

\section{Jimepamypa}

1. NATO CALS handbook. - 2000. - 307 p. 2. NATO standard AAP-20. NATO Programme Management Framework (NATO Life Cycle Model). - 2015. - 78 p. 3. Methods and Models for Life Cycle Costing. Final Report of Task Group SAS-054 / Research and technology organisation NATO. - 2007. 4. Повстяной О.Ю. Застосування CALS-технології для комплексного виготовлення корпусів водолічильників 3 використанням програмного комплексу Delcam // Lviv Polytechnic National University Institutional Repository http://ena.lp.edu.ua/ 2013. - C. 148-153. 5. Авдєсв О.М. Інтегрована логістична підтримка поставок авіадвигунів

та комплектуючих / Авдєєв О.М., Дмитрієв С.О., Тамаргазін О.А. // Авиационно-космическая техника и технология, 2006, № 10 (36). - С. 168-170. 6. Воїнов В.В. Інтегрована логістична підтримка зразків озброєння та військової техніки / Воїнов В.В, Бровко М.Б., Запара Д.М. // Системи озброєння і військова техніка. - 2014. № 1(37). - С. 12-15. 7. Кірпічніков Ю.А. Аналіз світового досвіду застосування інтеграційних технологій в автоматизованих системах управління / Кірпічніков Ю.А., Утюшев М.К., Закалад М.А., Головченко О.В., Васюхно С.I. // Збірник наукових праць Центру воєнно-стратегічних досліджень 
Національного університету оборони України імені Івана Черняховського. - 2016. - № 3. - С. 131-135. 8. Скворчевський О. Є. Аналіз зарубіжного досвіду побудови CALS-технологій для управління життєвим циклом озброєння та військової техніки / O.С. Скворчевський // Вісник Нац. техн. ун-ту "ХПІ" : зб. наук. пр. Сер. : Економічні науки. - Харків : НТУ "ХПІ", 2016. - № 48 (1220). - C. 75-80. 9. PLCS (Product Life Cycle Support) for Data Sharing between French MoD and Industry - Ratification, Experimentation and Implementation $/ 9^{\text {th }}$ NATO LCM Conference, 29 January 2013 y. - 38 p. Access mode: http://www.asdssg.org/c/document_library/get_file?p_1_id=47316\&folderId $=47379$ 10. Наказ № 517 від 19 грудня 2018 р. Про прийняття та скасування національних стандартів, прийняття зміни до національного стандарту/ Національний орган стандартизації Державне підприємство «Український науково-дослідний i навчальний центр проблем стандартизації, сертифікації та якості». - Київ, 2018. - 4 с. 11. Javier Pastor Sánchez Life cycle cost estimation procedure for a weapon system in
Spain / Javier Pastor Sánchez // Journal of the Spanish institute for strategic studies/ - 2015. - № 6. - C. 1-40. Access mode: http://revista.ieee.es/index.php/ieee 12. Указ Президента України Про членів Наглядової ради Державного концерну «Укроборонпром» від 17 березня 2014 року № 309/2014. 13. Розпорядження Кабінету Міністрів України від 31 січня 2018 р. № 42-р Про призначення члена наглядової ради Державного концерну "Укроборонпром". 14. Ungaro Alessandro R. Italian Defence Reform: Toward a New Logistics Support Model? / Alessandro R. Ungaro, Paola Sartori and Federico Palmieri // Documenti Instituto Affari Internazionaly. ISSN 2280-6164 - July 2017. - 14 p. 15. US Department of Defense, PBL Guidebook. A Guide to Developing Performance-Based Arrangements, 2016, p. 10, http://bbp.dau.mil/docs/PBL_Guidebook_Release_March_2 016_fnal.pdf. 16. Janatschek Peter Standards and Specifications The Basis for Life Cycle Management in NATO // Janatschek Peter / Data Group. S-Series Specification Day S1000 User Forum. - 2013. - 17 p.

\title{
CALS-КОНЦЕПЦИЯ ЛОГИСТИЧЕСКОЙ ПОДДЕРЖКИ ЖИЗНЕННОГО ЦИКЛА ВООРУЖЕНИЯ И ВОЕННОЙ ТЕХНИКИ: НАЦИОНАЛЬНЫЕ АСПЕКТЫ ВНЕДРЕНИЯ
}

\author{
Александр Евгеньевич Скворчевский (кандидат технических наук, доцент)
}

\section{Национальный технический университет «Харьковский политехнический институт», Харьков, Украина}

В статье обоснована актуальность внедрения интегрированной логистической поддержки жизненных ичиклов образцов вооружения и военной техники, которые проектируются, производятся, эксплуатируются и утилизируются в Украине. Показано, что наиболее эффективным и распространенным в мире инструментом реализации интегрированной логистической поддержки является CALS-концепичии (Continuous Acquisition and Life Cycle Support concept). Лидером в направлении исследований статьи являются Соединенные Штаты Америки, где CALS-конщепция зародилась 6 середине 80-х годов. Сегодня, несмотря на очень высокий уровень стандартизации в сфере CALSтехнологий и систем существуют наџиональные особенности имплементации CALS-концепции в практику менеджмента жизненного иикла образиов вооружения и военной техники разных стран. Целью статьи является выявление вызовов, которые могут возникнуть на пути внедрения CALSконцепции в украинский оборонно-промышленный комплекс и силовые структуры. Поставленная задача решалась путем анализа и обобщения опыта внедрения интегрированной логистической поддержки жизненного цикла образцов вооружения и военной техники (на основе CALS-технологий) в странах членах NATO, которые по территории, военному, промышленному, научному потенциалам можно сравнить с Украиной. В качестве таких стран были выбраны Франиузская Республика, Испания, Италия, Германия. Выделены вызовы и пути их преодоления, характерные для каждой из стран. Показано как этот опыт может быть применен в Украине. Так опыт Франиузской Республики обосновывает целесообразность интеграции имеющихся в государстве информационных систем, например, разного рода реестров, системы Прозорро т.д. с информационными системами поддержки жизненного ичкла вооружения и военной техники. Опыт Испании важен для прозрачного ценообразования стоимости жизненного цикла. Италия внедряет последнюю тенденцию в этой области - логистику эффективности. В Германии существует CALS-форум - платформа для объединения и обмена опытом специалистов. Данные исследования должны стать фундаментом для дальнейшего развития CALS-систем для образиов вооружения и военной техники, разрабатываемых и модернизируемых в условиях гибридной войны.

Ключевые слова: CALS-концепция, интегрированная логистическая поддержка, вооружение и военная техника, стоимость жизненного ичикла, логистика эффективности, поддержка жизненного цикла продукта, ISO 10303-239, CALS-форум Германии

\section{CALS-CONCEPT OF WEAPONS AND MILITARY EQUIPMENT LIFE CYCLE LOGISTIC SUPPORT: NATIONAL ASPECTS OF IMPLEMENTATION}

Oleksandr Skvorchevskyi (Candidate of technical sciences, associated professor) 


\section{National Technical University "Kharkov Polytechnic Institute", Kharkiv, Ukraine}

The topicality of implementation of life cycle integrated logistic support for weapons and military equipment that are designed, manufactured, operated and disposed in Ukraine is substantiate in the article. It was shown that the most effective and widespread in the world tool for implementing integrated logistics support is the CALS-concept (Continuous Acquisition and Life Cycle Support). The United States of America is the leader in this field, where the CALS-concept was originated in the mid-80s. Today, despite the very high level of standardization in the field of CALS technologies and systems, there are national peculiarities of the implementation of the CALS concept in the practice of weapons and military equipment life cycle management for different countries. The challenges identification that may arise in the way of the implementation of the CALS concept in the Ukrainian defence industry and security forces is the purpose of the article. The task was solved by analysing and summarizing the experience of introducing life cycle integrated logistical support for armaments and military equipment (based on CALS technologies) in NATO member countries, which can be compared with Ukraine in territory, military, industrial and scientific potentials. The next countries were chosen: The French Republic, Spain, Italy and Germany. For each country were identified the most important challenges and ways of their overcome. The article shows how this experience can be useful for Ukrainian defense industry and Armed Forces. The experience of the French Republic substantiates the expediency of integrating the information systems existing in the state, for example, various kinds of registries, the Prozorro system, etc. with information systems support the life cycle of. The Spanish experience is important for transparent pricing of life cycle of weapons and military equipment. Italy introduces the latest trend in this area - performance-based logistics. There is a CALS-forum of Germany - a platform for uniting and sharing the experience of specialists in this field. These studies should be the basement for the further development of CALSsystems and technologies for Ukrainian weapons and military equipment, which will be developed and upgraded in a hybrid war.

Key words: CALS-concept, integrated logistics support, weapons and military equipment, life-cycle cost, performance-based logistics, product life cycle support, ISO 10303-239, CALS forum Deutschland

\section{References}

1. NATO CALS handbook. - 2000. - 307 p. 2. NATO standard AAP-20. NATO Program Management Framework (NATO Life Cycle Model). - 2015. - 78 p. 3. Methods and Models for Life Cycle Costing. Final Report of Task Group SAS-054 / Research and technology organisation NATO. 2007. 4. Povstjanoj O.Ju. Zastosuvannja CALS-technolohiï dlja kompleksnoho vyhotovlennja korpusiv vodoličyl' nykiv z vykorystannjam prohramnoho kompleksu Delcam // Lviv Polytechnic National University Institutional Repository http://ena.lp.edu.ua/ 2013. - C. 148153. 5. Avdjejev O.M. Intehrovana lohistyčna pidtrymka postavok aviadvyhuniv ta komplektujučych / Avdjejev O.M., Dmytrijev S.O., Tamarhazin O.A. // Avyacyonnokosmyčeskaja technyka y technolohyja, 2006, \# 10 (36). - S. 168-170. 6. Voünov V.V. Intehrovana lohistyčna pidtrymka zrazkiv ozbrojennja ta vijs' kovoï techniky / Voïnov V.V, Brovko M.B., Zapara D.M. // Systemy ozbrojennja i vijs' kova technika. - 2014. - \# 1(37). - S. 12-15. 7. Kirpičnikov Ju.A. Analiz svitovoho dosvidu zastosuvannja intehracijnych technolohij $\mathrm{v}$ avtomatyzovanych systemach upravlinnja / Kirpičnikov Ju.A., Utjušev M.K., Zakalad M.A., Holovčenko O.V., Vasjuchno S.I. // Zbirnyk naukovych prac' Centru vojenno-stratehičnych doslidžen' Nacional' noho universytetu oborony Ukraïny imeni Ivana Černjachovs' koho. - 2016. - \# 3. - S. 131-135. 8. Skvorčevs' kyj O. Je. Analiz zarubižnoho dosvidu pobudovy CALS-technolohij dlja upravlinnja žyttjevym cyklom ozbrojennja ta vijs' kovoï techniky / O.Je. Skvorčevs' kyj // Visnyk Nac. techn. un-tu "ChPI" : zb. nauk. pr. Ser. : Ekonomični nauky. - Charkiv : NTU "ChPI", 2016. - \# 48 (1220). - S. 75-80. 9. PLCS (Product Life Cycle Support) for Data Sharing between French MoD and
Industry - Ratification, Experimentation and Implementation $/ 9^{\text {th }}$ NATO LCM Conference, 29 January 2013 y. - 38 p. Access mode: http://www.asdssg.org/c/document_library/get_file?p_1_id=47316\&folderId $=47379$ 10. Nakaz \# 517 vid 19 hrudnja 2018 r. Pro pryjnjattja ta skasuvannja nacional' nyx standartiv, pryjnjattja zminy do nacional' noho standartu/ Nacional' nyj orhan standartyzaciji Deržavne pidpryjemstvo «Ukrajins' kyj naukovo-doslidnyj i navčal' nyj centr problem standartyzaciji, sertyfikaciji ta jakosti». - Kyjiv, 2018. - 4 s. 11. Javier Pastor Sánchez Life cycle cost estimation procedure for a weapon system in Spain / Javier Pastor Sánchez // Journal of the Spanish institute for strategic studies/ - 2015. - № 6. - C. 1-40. Access mode: http://revista.ieee.es/index.php/ieee 12. Ukaz Prezydenta Ukrajiny Pro členiv Nahljadovoji rady Deržavnoho koncernu «Ukroboronprom» vid 17 bereznja 2014 roku \# 309/2014. 13. Rozporjadžennja Kabinetu Ministriv Ukrajiny vid 31 sičnja 2018 r. \# 42-r Pro pryznačennja člena nahljadovoji rady Deržavnoho koncernu "Ukroboronprom". 14. Ungaro Alessandro R. Italian Defence Reform: Toward a New Logistics Support Model? / Alessandro R. Ungaro, Paola Sartori and Federico Palmieri // Documenti Instituto Affari Internazionaly. ISSN 2280-6164 - July 2017. - 14 p. 15. US Department of Defense, PBL Guidebook. A Guide to Developing Performance-Based Arrangements, 2016, p. 10, http://bbp.dau.mil/docs/PBL_Guidebook_Release_Marc h_2016_fnal.pdf. 16. Janatschek Peter Standards and Specifications The Basis for Life Cycle Management in NATO // Janatschek Peter / Data Group. S-Series Specification Day S1000 User Forum. - 2013. - 1 